\title{
Artefact
}

Techniques, histoire et sciences humaines

\section{Materiality of marine sciences in late Imperial Russia and early Soviet Union: Research vessels, instruments, laboratory practices}

L'histoire matérielle des sciences maritimes à la fin de la Russie impériale et au début de l'Union soviétique : navires de recherche, instruments, pratiques de laboratoire

Julia Lajus

\section{(2) OpenEdition}

\section{Journals}

Electronic version

URL: https://journals.openedition.org/artefact/10129

DOI: $10.4000 /$ artefact. 10129

ISSN: 2606-9245

Publisher:

Association Artefact. Techniques histoire et sciences humaines, Presses universitaires du Midi

\section{Printed version}

Date of publication: 7 October 2021

Number of pages: $245-265$

ISBN: 978-2-8107-0755-3

ISSN: 2273-0753

Electronic reference

Julia Lajus, "Materiality of marine sciences in late Imperial Russia and early Soviet Union: Research vessels, instruments, laboratory practices", Artefact [Online], 14 | 2021, Online since 07 October 2021 , connection on 08 October 2021. URL: http://journals.openedition.org/artefact/10129 ; DOI: https:// doi.org/10.4000/artefact.10129

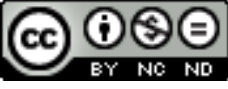

Artefact, Techniques, histoire et sciences humaines est mise à disposition selon les termes de la Licence Creative Commons Attribution - Pas d'Utilisation Commerciale - Pas de Modification 4.0 International. 


\section{Materiality of marine sciences in late Imperial Russia and early Soviet Union: Research vessels, instruments, laboratory practices}

Julia Lajus

\section{Abstract}

The paper discusses the materiality of marine science in Russia from the example of the Barents Sea. This sea became a scientific frontier in the late nineteenth century and in the first decades of the twentieth century by being included into the international research programme of the International Council for the Exploration of the Sea. The advantage of Russia was the possibility to get the very first Europe research vessel. The legacy of this period lasted into early Soviet time, when oceanography also developed around a research vessel that became a core of the Floating Maritime Institute. The study of the materiality of research is enriched by a focus on gender in marine science.

\section{Keywords}

Barents Sea, fisheries, gender in science, history of oceanography

99 Julia Lajus, « Materiality of marine sciences in late Imperial Russia and early Soviet Union: Research vessels, instruments, laboratory practices », Artefact, 14, 2021, p. $245-265$. 


\section{L'histoire matérielle des sciences maritimes à la fin de la Russie impériale et au début de l'Union soviétique : navires de recherche, instruments, pratiques de laboratoire}

\section{Résumé}

L'article étudie l'histoire matérielle des sciences maritimes en Russie à partir de l'exemple de la Mer de Barents. Cette mer est devenue une frontière scientifique à la fin $d u x x^{e}$ siècle et dans les premières décennies $d u x x^{\mathrm{e}}$ siècle par son inclusion dans le programme de recherche international du Conseil international pour l'exploration de la mer. L'avantage de la Russie était la possibilité d'obtenir le tout premier navire de recherche européen. L'héritage de cette période s'est prolongé jusqu'au début de l'ère soviétique, lorsque l'océanographie s'est également développée autour d'un navire de recherche qui est devenu le noyau du Floating Maritime Institute. L'histoire matérielle de la recherche est enrichie par l'accent mis sur le genre dans les sciences maritimes.

\section{Mots-clés}

Mer de Barents, pêcheries, genre dans les sciences, histoire de l'océanographie
A
ll scientific research highly depends on its material supply, be it laboratory buildings, instruments, collections, chemical com- pounds. For marine sciences the dependence on instruments is especially evident because even for getting into the sea in order to study it, a well-equipped vessel is needed. The ship itself, as it was skilfully demons- trated recently, could become a "space of circulation " for knowledge, 
research and organizational practices ${ }^{1}$. Only very few characteristics of the sea could be observed by human eyes - without instruments, most of it cannot be grasped. Although the title of the seminal book on history of scientific instruments for oceanography is No Sea Too Deep, it was certainly a challenge to study the deep waters and quite sophisticated instruments were needed to be designed for this purpose ${ }^{2}$. It is well known that instruments serve as mediating technologies ${ }^{3}$. When new technologies are used, new scientific objects come into being. Instruments open the possibility to perceive phenomena otherwise inaccessible for the human sense organs, creating therefore new scientific reality. At the same time, they create an area of expertise requiring specific knowledge on how to deal with this or that device, and therefore shape the community of experts. Eventually, instruments generate an idea of the world, which exists beyond the limits of our perception and has its own rules. During recent decades more and more diverse technologies including automatic measurements at all depths and underwater filming transformed the ocean from robust frontier to fragile environment, making it "accessible" ${ }^{\text {. }}$ But a hundred years ago the situation was different.

This paper discusses the development of the materiality of the marine sciences in Russia, based on the example of the studies of the Barents Sea that became a scientific frontier in the late nineteenth century and in the first decades of the twentieth century. The Barents Sea was included into the international research programme of the International Council for the Exploration of the Sea (ICES), founded in $1902^{5}$. This led to the necessity for Russian scientists to use the same methods and instruments as other European countries - members of ICES. The transfer of methodology went along with the transfer of instruments and tacit knowledge of how to use them. The advantage of Russia was the possibility to order in Germany in 1898 the very first vessel for marine research in Europe. The legacy of this period lasted into the early Soviet period, when oceanography also developed around research vessels that became a core of the Floating Maritime Institute, founded in 1921.

1. Bekasova, 2020.

2. McConnell, 1984.

3. de Boer, 2020.

4. Rozwadowski, 2018.

5. Rozwadowski, 2002. 
The foundation of marine sciences in Russia is strongly connected with its northern frontier, the White and Barents seas. In my previous publications, I described the development of field stations in this part of Russia and I analysed the rich and long-lasting connections between Russian and Scandinavian marine scientists ${ }^{6}$. I also discussed the demand for oceanographic research that was related to the desire to improve fisheries practices and the life of local fishermen; these needs were articulated by diverse institutions of emerging civil society, local and central state officials and were supported by scientists who saw in them very good opportunities for more financial support of science ${ }^{7}$. In this paper I will focus more on the technologies used in the northern marine sciences and especially on the gendered component of the practices of dealing with these technologies.

\section{Materiality and practices of the Russian northern oceanography in its formative decade, 1898-1908}

The emergence of modern biological oceanography in Russia is associated with the work of the Murman Scientific-Fisheries Expedition, the first comprehensive expedition, the activities of which lasted, with greater or lesser intensity, for ten years, from 1898 to $1908^{8}$. The expedition was planned at the specially formed Northern Commission at St. Petersburg in 1897. The Commission was organized by the members of the philanthropy Committee for the Aid of Pomors (local inhabitants of the White Sea coasts), which was founded after the disaster of 1895, when twenty-five fishing vessels which were returning from the fisheries in the Barents Sea were lost in a storm?. The Committee was closely related to the Imperial Society for the Promotion of Russian Trade and Shipping, a major association which united merchants, mariners, and state bureaucrats in relation to maritime trade and navigation ${ }^{10}$. A member of the royal family, grand prince Alexandr Mikhailovich, who was a high-ranking naval officer, became a patron of the Committee. He was a close friend of the Emperor

\footnotetext{
6. Lajus 2013a; Lajus 2013b.

7. Lajus, 2018.

8. Lajus, 2002.

9. Lajus, 2018.

10. Kulikova, 2018.
} 
Nicholas the Second and was married with his sister Ksenia. Alexandr Mikhailovich took active part in the discussions on the equipment of the future expedition and was especially interested in the design of the research vessel $^{11}$. The powerful Minister of Finances Sergei Yu. Witte supported the plan for the expedition.

At that time the United States were the only country that possessed specially designed research vessels. Thus, the US experience was favourably presented at the discussions of the Commission as an example to follow by Russia. When Capitan Odintsov presented to the grand prince two versions for the research vessels - one modest with a relatively small vessel to be built, and another one far more ambitious - Alexandr Michailovich preferred the ambitious plan ${ }^{12}$. However, the discussions continued. The construction of a large modern research vessel required much time but the Committee and a newly appointed leader of the future expedition zoologist Nikolai Knipowitsch were eager to begin research immediately ${ }^{13}$. Thus, two options were discussed: either to order a new large vessel but simultaneously buy a small one for an immediate start, or to buy an old large vessel and use it for a longer time period and then return to the plan of constructing a new one. The material of the vessel was also questioned (steel vs. wood). The steel vessel would be much faster. This was important for the mobility of the expedition that was intended to study the vast areas of the Barents Sea. On the other hand, wooden vessels had been proven to be resistant to ice - the example of the Norwegian wooden ship Fram used by Fridtjof Nansen, whose expedition had just returned with victory and glory was on everybody's tongue. Finally, the decision was made to order a new steel vessel abroad for the future and to buy a small wooden vessel in Norway for the upcoming years. In order to be able to carry out the programme of the expedition, first of all to build an expensive research vessel, the Committee applied to the public and by 1898 it had already received almost 150,000 roubles in donations. Subsequently, the Committee also began to receive substantial state subsidies.

The search for the right place to build the ship also took time. It was decided from the very beginning to order its construction to a foreign firm

11. Trudy Severnoi Komissii, 1898.

12. Odintsov, 1898.

13. I use the German spelling of the name that he used in his publications, but the English spelling Knipovich is often used as well. 
located abroad. Offers were received from several countries. The best one in terms of price, quality, and timeframe came from the Bremer Vulcan factory located in Vegesack, a northern district of the city of Bremen in Germany. The small wooden ship was also found quickly in Norway; it was named Pomor and was ready for use by summer 1898 .

However, the absence of research vessels was not the only obstacle that needed to be solved before the expedition could begin to work. It was crucial to obtain modern instruments and materials and to learn how to use them in accordance with rapidly developing research methods in oceanography. To obtain both - material supplies and relevant knowledge - the Committee sent Knipowitsch on a tour to northern Europe. The plan was to visit as many marine research institutions as possible and to meet with practitioners. From the very beginning the aim was to work with the same methods as Western scientists, so that the results of the expedition's work could be compared with theirs.

Knipowitsch not only visited marine biological stations and universities but even participated in some field work ${ }^{14}$. For instance, together with the Norwegian ichthyologist Johan Hjort and the Danish zoologist Carl G.J. Petersen he took part in the testing of a small trawl for zoological sampling. It had recently been designed by Petersen and soon became known as the Petersen trawl. One such trawl was ordered for the expedition. It was used as early as 1898 onboard of the Pomor ${ }^{15}$.

The cornerstone of modern biological oceanography is quantitative research. The Scandinavian countries led the field in late nineteenth- and early twentieth-century modernisation of the use of marine resources. The development of fisheries oceanography and marine biology was one of the expressions of the modernist thrust of the Scandinavian countries, which soon spread rapidly to other areas. Scientists from these countries designed a new scientific program, which attempted to link fish to their ocean environment and was disseminated on an international scale, leading to the foundation of the International Council for the Exploration of the Sea (ICES) in 1902 by eight founding nations (Denmark, Germany, the Netherlands, Norway, Sweden, Russia and Finland separately, and the United Kingdom). This objective at least partly redirected the attention

14. Knipowitsch, 1897

15. For more details see Lajus, 2013b. 
of fishery scientists from studies of fisheries as a socio-economic activity towards environmental issues, and this was very much in line with developments in the environmental sciences in Russia as well. ICES still exists as a leading multidisciplinary forum for the exchange of information and providing scientific advice in the marine sciences, including fisheries in the North Atlantic, notably the Baltic, North and Barents seas.

At the time of the Murman Scientific-Fisheries Expedition, their methods were just beginning to be developed. But the fact that mass material was needed to identify patterns was quite obvious even then. Knipowitsch believed that it was necessary to obtain the studied animals in large numbers, as many issues of fish and other animal biology could only be clarified on the basis of the study of abundant material. It was necessary to introduce large, powerful tools into the equipment of scientific fishing expeditions. Fishing gear thus had to be used as scientific tools.

Knipowitsch considered as scientific-fishery all studies using "strong " fishing gear even to collect such groups of animals that play no role in the fishery, i.e. quantitative studies that allowed to determine at least the relative abundance of organisms in different parts of the sea. One of them was a special trawl designed by Petersen, which combined the design of an otter trawl with the so-called Danish eel trawl. Having tested this trawl in Kristianfjord with Petersen, Knipowitsch brought it back to Russia and used it for the first time for zoological and ichthyological collections during the Murman expedition ${ }^{16}$.

Paying deep attention to research methodology, Knipowitsch was also serious about the methodological part of the expedition's work. During his trip abroad he tried to learn and assimilate all the latest methods and obtain the latest instruments and fishing gear for the work of his expedition. In addition to the hydrological and meteorological observations, the expedition staff carried out extensive marine fauna surveys and very regular fishing experiments in different locations, with different implements and with different bait. The difficulties of working on a sailboat, which was entirely dependent on the weather, prevented systematic research. Thanks to Arkhangelsk Governor A.P. Engelhardt's interest in the expedition's activities, it was sometimes possible to use the administrative steamer Murman for expedition work. 
The new research vessel was ready by the beginning of 1899 . She was called Andrei Pervozvanny after the name of the Russian Saint - a patron of the Russian navy. It was Europe's first and one of the world's first purpose-built vessels for marine exploration. She was 151 feet long overall, 26 feet wide, 10 feet draught and 336 register tons displacement. It was capable of speeds in excess of 10 knots. A special space for the laboratory was constructed in the aft deckhouse and consisted of two rooms. One was for rough work, where samples were taken apart, fish were dissected and measured, aquariums and collections were kept. The second room was for microscopy work and chemical analyses. The vessel also had a very strong steam winch for working with fish trawls, Petersen trawls and ordinary zoological trawls. A weaker winch with two wires wound around it was situated on the foredeck. A thick steel winch was used for dredging and fishing large pelagic nets and a thin flint-bronze winch served for lowering thermometers, bathometers and trawls. In addition, a small davit was placed at the front and rear of the deck, to which were attached the counters used when working with the bronze rope. These davits were used to lower small pelagic nets and a Secchi disc to determine water clarity. Such a construction of the vessel made it possible not only to move with great ease from one job to another and perform them quickly, but also to perform different jobs at the same time. Thus, it was possible to work with pelagic nets or hydrological instruments in the bow of the vessel while the trawl was being lifted.

On April 16 ${ }^{\text {th }}, 1899$ Andrey Pervozvanny reached Copenhagen, where the members of the expedition met Carl Petersen as well as the future President of the International Council for the Exploration of the Sea, Christian Frederik Drechsel. Then Andrey Pervozvanny proceeded to Christiania (Oslo), where members of the expedition were welcomed by the city authorities and university professors, including Fritjof Nansen. After Christiania Andrey Pervozvanny visited other Norwegian towns on its way to the Russian Barents Sea coast - Drøback, Bergen, Trondheim, Bode, Tromsø, Hammerfest, Vardø. Everywhere the members of the expedition met with local scientists, visited museums, aquaria and biological stations. In Trondheim, they bought one more small boat, later named Rybak (Fisherman), for the expedition. In the same year Hjort requested 
the building of a research vessel, but he chose an English-type trawler in contrast to the more yacht-like Russian vessel ${ }^{17}$.

The zoological and especially ichthyological equipment of the expedition were acknowledged as excellent by Knipowitsch, even in comparison with the leading marine research institutions in Europe that he visited in 1897 when preparing to lead his expedition ${ }^{18}$. In his opinion, special scientific fishing, especially with the use of the latest, significantly stronger fishing gear, opened a new stage in the development of fisheries oceanography ${ }^{19}$. If before ichthyologists had often had to simply use the results of fishermen's catches, now they could catch fish themselves, choosing specific locations and combining different fishing gear. At the same time, scientific practice in the field of capture fisheries research was, in fact, practically indistinguishable from actual fishing practice in terms of the methods and even the fishing gear used. The Petersen dragnet remained the only instrument designed specifically for research, and it was used in general faunal studies rather than in capture fisheries. This similarity of fishing and scientific research practices made it possible for the Committee to require the expedition to catch fish for sale, not just for scientific work.

A full series of works at the station was carried out from the steamer as follows: upon arrival at the planned point, depth was measured and the ground was determined; then a prepared and baited line was set out; while the line remained in the water, the steamer fished near it with trawls, pelagic nets; a series of temperatures and water samples were taken at various depths, and water transparency was determined. Having completed this work, the steamer would return to the tier, select it - and the station was finished. A complete station took up to twelve hours or more. Sometimes the weather allowed only trawl work, accompanied, if possible, by a series of temperature determinations.

In 1900, for the first time, work was carried out on a system of defined profiles. A voyage along the $33^{\text {rd }}$ (Kola) meridian, which would later become one of the most important sections to be carried out by the expedition under the International Council programme, took place. Serious methodological difficulties, particularly in determining water salinity, made it

17. Solemdal, Serebryakov, 2002, p. 77.

18. Knipowitsch, 1900, p. 451.

19. Knipowitsch, 1900, p. 454. 
impossible to produce a hydrological chart and this greatly devalued the hard-won hydrological data of 1899 and 1900. At the same time, numerous measurements of water temperature made it possible to clarify to a large extent the living conditions of animals at different depths and to take the first steps towards establishing the distribution of fish in relation to temperature.

Knipowitsch argued that it was necessary to join the International Bureau Council, at least for the duration of the initial work, expressing the hope that " during that period we will have fully developed the technique for the new research, people will be prepared to work independently and then it will indeed be superfluous to stick to an international institution in the place of the Russian. ${ }^{20}$ Connections with ICES and its founding fathers, first of all Swedish oceanographer Otto Pettersson was very important for Knipowitsch and his expedition.

The surviving correspondence shows that for several years Pettersson helped Knipowitsch to establish the methodological part of the oceanographic research $^{21}$. As early as autumn 1898, Knipowitsch informed Pettersson of the first hydrographic data from the exploration expedition and hoped to link his research with that of Scandinavian scientists ${ }^{22}$. Pettersson regularly sent Knipowitsch his work as well as instruments - the famous Pettersson bathometers and salinity tables - and gave him various pieces of advice ${ }^{23}$. Particularly difficult for Knipowitsch was mastering the methods for determining the salinity of seawater. In 1899 Knipowitsch complained to Pettersson that the chemist he had hired for the expedition was not sufficiently qualified ${ }^{24}$. In the spring of 1900 , Knipowitsch visited Petterson in Stockholm and one of the main issues discussed at that meeting was the determination of salinity on the Murman expedition.

In the autumn of that year, Knipowitsch sent his assistant Leonid Breitfuss to be trained by Pettersson and the Danish oceanographer Martin Knudsen in oceanographic research methods. But this was not enough. Knipowitsch instructed Breitfuss to find an experienced chemist for the

20. Russian State Historical Archives coll. 398, inv. 72, f. 28059, 1. 137- 138.

21. Lajus, 2013b.

22. Knipowitsch to Pettersson, 1898.

23. Knipowitsch to Pettersson, 1900.

24. Knipowitsch to Pettersson, 1899. 
Murman expedition abroad. Breitfuss considered himself as a modern, multidisciplinary marine scientist. This can be seen from the photograph that he most probably staged himself when overwintered at the headquarter of the expedition at the Barents Sea coast. While at the center of the picture we see skies, and this is obvious visual reference to Fridtjof Nansen, whom Breitfuss admired as many other young polar scientists of that time, the large corner is occupied by the chemical laboratory - the most important laboratory technology for oceanographers. A chemical laboratory was needed to determine the salinity of water with the high precision required to understand marine currents.

In the summer of 1901, Pettersson's assistant Augusta Palmqvist visited the expedition, helped set up salinity determinations and handled the large volume of samples already collected ${ }^{25}$ She was one of the first women in the world to devote her outstanding talent and many years of effort to ocean research, especially her contribution to the methodical improvement and standardisation of oceanographic methods in the early twentieth century. Born in Stockholm in 1861, Augusta Palmqvist graduated from the Royal Higher Schoolmistress Training College in 1880 and soon afterwards joined the Atheneum for Girls, where she worked until her retirement in $1923^{26}$. She also did assistantship work for the Swedish polar explorer S.A. André. Palmqvist's articles as sole author, as well as in co-authorship with Pettersson, mainly concern the determination of carbon dioxide in water and air, but as an assistant she analysed the salinity of most seawater samples in Pettersson's oceanographic research ${ }^{27}$. She also helped Pettersson to determine the oxygen content of the water in $1890^{28}$.

Because the gradient of sea water salinity determines the currents in the ocean, an analysis of salinity measured with high precision enabled Knipowitsch to draw the first detailed hydrographic map of the Barents Sea. Knipowitsch wrote to Pettersson and Hjort about the success of the expedition's research ${ }^{29}$. The latter referred to Knipowitsch's outstanding contribution to oceanography many years later as the fact that "he was the

25. Knipowitsch N.M. Otchet nachalnika Murmanskoi nauchno-promyslovoi ekspeditsii. Russian State Historical Archives. coll. 116, inv. 1, f. 17, l."38.

26. Palmquist, 1931.

27. Svansson, 2004.

28. Lajus, Svansson, 2003.

29. Knipowitsch to Pettersson, 1902; Knipowitsch to Hjort, 1901. 
first to describe the distribution of the branches of the Gulf Stream in the Barents Sea and tried to relate the distribution of fish to $\mathrm{it}^{30}{ }^{30}$.

Although it developed slowly, the industrialization of Russian fisheries inevitably prompted new questions and encounters between traditional users of resources and supporters of the new industrial mode of production. These encounters had already started to become visible in the story of the Murman expedition. After several years, it became obvious that in spite of the expedition's success in obtaining high-quality scientific knowledge on oceanographic patterns in the Barents Sea, as well as discoveries on fish distribution and finding new off-shore fisheries grounds, local fishing communities were proving unable to introduce this new knowledge into practice. Local authorities had no ability to mediate between scientists and fishing communities. Private capital was not interested in investing in fisheries in this remote northern region because there were already enough profitable fisheries in the south, where the whole infrastructure was far better developed. Thus, in 1900 the expedition was accused of "forgetting the needs of local fishermen in favor of foreign science ${ }^{31}$ ". The expedition research vessel worked with a trawl and discovered many good fishing places that would have been profitable for trawling. However, the published results of the expedition's exploratory fishing did not bring any immediate profit for Russian fishermen, who had no suitable vessels, but did lead to considerable earnings for foreign trawlers, especially English ones. The Murman expedition was then accused of facilitating the arrival to the shores of the Barents Sea of British trawlers.

During the following five years, after Nikolai Knipowitsch lost his position as head of the expedition and his former assistant Leonid Breitfuss replaced him, the expedition managed to maintain a high level of scientific research despite being forced by the Committee for the Aid to Pomors to fulfill numerous practical tasks, such as building baths for seasonal fishers and maintaining a school for the orphans of dead fishers ${ }^{32}$. The expedition also attempted to introduce new types of fishing vessels, which were mostly borrowed from Norwegians, but they were too expensive for local Russian fishermen.

30. Hjort, 1939.

31. Anon., 1900, p. 4.

32. Breitfuss, 1905. 
The North was the first region in Russia where local fishermen met face to face with new industrial fisheries. The future development of fisheries was actively discussed at meetings of the newly established local Arkhangelsk Society for the Study of the Russian North. Participants of these meetings formed two distinct groups. One group consisted of industrialists and scientists who advocated attracting capital investment for the development of large industrial fisheries based on trawling technology. Another group of local representatives supported small-scale inshore fisheries and argued against the development of industrial fisheries. The first group was influenced by the example of Great Britain, while the second preferred to follow the Norwegian path.

Basic knowledge about fishing grounds that had been obtained by the Murman expedition needed to be transformed into practical recommendations. This task was taken up by several private industrialists who bought English trawlers and, in addition to their commercial fishing, systematically surveyed the waters. As in Norway, most local fishers in the Russian North opposed the idea of the development of trawling fisheries. The trawl was declared a "rapacious foreign device ", highly damaging for marine life and threatening for the traditional artisanal fisheries.

The invasion of English trawlers, along with Norwegian fishing vessels and marine hunting expeditions, in a region where no formal borders of territorial waters had been established redirected the attention of central and local authorities from their concerns about the modernization of fisheries towards concerns about guarding the region from foreigners. It also became evident that knowledge itself could not help without significant changes in technology. Two decades later, however, when industrialization became a definite goal of the Soviet government, the scientific legacy of Knipowitsch's program led to the foundation of Soviet industrial fishing.

\section{Disruption and continuation in the materiality of marine research in post- revolutionary Soviet North, 1921-1933}

The turbulent period of the First World War and the Russian Civil War very much affected life and scientific research in the North. Some level of research continued in that period, even under the rule of provisional 
government and British-American-French intervention of 1918-1919. It was mostly practically oriented towards fisheries, especially towards experiments with trawling ${ }^{33}$. The positive legacy of the war materialized in major infrastructure development - such as the construction of the Murmansk railway that connected the Barents Sea coast with the capital. Another legacy was inheritance of twelve British military trawlers that were transferred to fisheries.

The European North of the country that was subordinated under the Soviet power as late as the beginning of 1920 became crucially important both strategically as well as a source of natural resources, including marine ones. Two newly established scientific institutions competed for state support: the Northern Scientific Commercial Expeditions and the Floating Maritime Research Institute. The Northern Scientific Commercial Expeditions was a large multidisciplinary institution founded in 1920 that inherited the name of the Murman Scientific-Fisheries Expedition although it had much wider and ambitious tasks: prospecting and mapping all kind of resources, including geological and other terrestrial resources. It got under its supervision a new wooden vessel in Arkhangelsk that was under construction but lost its owner after the revolution. Its construction needed investment and the expedition was too slow in that. Because of that the vessel was taken by another scientific institution, the Floating Maritime Research Institute (Plavmornin in Russian), which was led by the Moscovite zoologist Ivan Mesyatsev, who was close to the communist establishment. The very name of the institute was a truly fortunate invention by the organisers. They did not propose to the Soviet government to set up another institute which needed a research vessel - many institutes at the time needed such a vessel as there were non of them in the whole new country - but to create a research vessel as an institute. The vessel was put first in the whole project. The institute's organisers even did not ask for any premises in Moscow for their work - only a vessel. Against the background of large-scale initiatives in the first post-revolutionary years, when scientists sought to create powerful institutions with many branches (that existed at least on paper), many of which were called "main" and "central", Mesyatsev's organizational idea found support: head of government Vladimir Lenin signed the decree of the foundation of the Institute. 
Mesyatsev believed that three conditions were necessary for the successful operation of the Institute: a cohesive team of scientists, the research vessel and a coastal base. After a decree was passed for the Plavmornin' work, permission was obtained to temporarily use the icebreaker Malygin. There were very few icebreakers at the time, and this was the first time an icebreaker had been allocated specifically for scientific research since Admiral Stepan Makarov with his first Russian icebreaker Yermak. The organizers of the Plavmornin, however, dreamed of having their own research vessel.

Mesyatsev skilfully used the controversy that had arisen between the Northern Expedition and the local authorities to achieve the transfer of the unfinished wooden vessel that was built following the Norwegian model of the marine hunting vessels, which were suitable for navigation among the ice, to the institute. Public attention, support by the Arkhangelsk city authorities and efforts by the Northern Shipping Company allowed the construction to be completed amazingly fast by the fifth anniversary of the revolution in November 1923. Some necessary elements were taken from other vessels, including naval ones, which shows how important the future work of Plavmornin was considered by the authorities. The first Soviet research vessel kept its initial name Persei. It was a two-mast steam-sailing schooner of 41,5 m length and displacement of 550 tonnes. The vessel was equipped with seven scientific laboratories ${ }^{34}$. The first voyage of the Persei took place in 1923. The route was along the $41^{\text {st }}$ meridian from the Murmansk coast northwards to the ice edge. The main task was hydrological observations and their comparison with data obtained in 1921 on the Malygin and with the materials of the Murman expedition. The head of the expedition was Nikolai Zubov, head of the hydrological department of the Plavmornin ${ }^{35}$. This was a really complex expedition - at each station scientists of different specialities carried out observations: hydrologists and planktonologists, hydrochemists, geologists, zoologists and ichthyologists. The subsequent processing of materials was also carried out by individual specialists, and the results were therefore accumulated and analysed quickly. The organisation of the survey was a considerable step forward compared with the Murman expedition.

34. Zenkevich, 1941, p. 72.

35. Vasnetsov, 1974, p. 102. 
Julia Lajus

The Plavmornin's work was based on an integrated method and quantitative research methods. The integrated method was understood as the coordinated work of scientists of different disciplines in one expedition on one vessel. A wide variety of materials were taken at one station at sea. As the hydrologist V.A. Vasnetsov recalled: "The order of cuts, whether in the open sea or in the ice, has long been firmly established. Twenty minutes before the ship stopped at the station the watchman woke up the hydrologists, planktonologists and geologists. They were the first to begin observations... As soon as the ship stopped, all instruments went into the water. Twenty minutes before the end of their observations the hydrologists awoke those who had to work on the ship with dredges, trawls and other instruments ${ }^{36}$."

In 1929 Plavmornin was merged with the Murman Biological Station to form the State Oceanographic Institute (GOIN), which existed until 1933 when it was reorganised following the arrest of some of its staff ${ }^{37}$. By 1930, there were five sections at GOIN: physical oceanography (with departments of hydrophysics, hydrology and hydrochemistry), hydrobiology (with departments of benthos, plankton, ichthyology, bacteriology and physiology), geomineralogy (with departments of biogeochemistry and marine sediments), paleogeography and the Murman Biological Station that lost its independence and joined the institute in 1929. This variety of research topics was carried out by a total of 34 scientific and 13 scientific-technical staff. An important achievement was the creation of a small expeditionary fleet which, apart from the flagship Persei included the motorboat Nikolai Knipowitsch, purchased in Bergen, Norway in 1928, the small station's schooner Alexander Kovalevsky, built before the revolution, and two small motorboats. Now when Persei was based in the ice-free harbour in the Kola Bay, it was possible to carry out year-round oceanographic research.

The motorboat Nikolai Knipowitsch with the displacement of 100 tons only was the second Soviet research vessel for northern oceanography. It was small but could take about 6-8 scientists on board who worked in two small laboratories, in addition to the 12 members of the $\mathrm{crew}^{38}$. It took the

36. Vasnetsov, 1974, p. 141.

37. Lajus, 2013a.

38. Tsirkunov, 2006. 
responsibility of sampling along the Kola meridian when Persei was busy with more distant cruises. The most known achievement of this research vessel was the first circumnavigation of Franz Josef Land in history, under the leadership of Nikolai Zubov; this was fulfilled in the framework of the Second International Polar Year in 1932-1933 ${ }^{39}$. It was an absolute record in the high Arctic for such a small vessel. Among scientists in this voyage were not only male, but also female scientists - not a fully unique situation for Soviet marine expeditions. It is known that by the end of the 1920s almost one quarter of researchers and graduate students in the Soviet Union were women ${ }^{40}$, among them marine scientists. Maria Klenova, a marine geologist, was on board of Nikolai Knipovich when it went around Franz Josef Land. As she remembered, " on a small vessel without any comfort, with very meagre supplies - often even without warm clothes in polar conditions, when it entered a storm, became stuck on ice, remaining without fresh water or almost without food, female scientists shouldn't only fulfil their scientific work but should also fight for their right to work equally with men..${ }^{41}$ ".

Since 1925, she had already taken part in many Plavmornin expeditions and she was often not the only woman on board. When she drew up a list of the female scientists who had taken part in expeditions on Persei, it included 12 women in addition to herself $f^{42}$. Ivan Mesyatsev, the director of Plavmornin was a firm believer in equal rights of male and female scientists, including the participation and even leading of marine scientific expeditions ${ }^{43}$. Maria Klenova, as the oldest and most experienced of the institute's staff, regularly served as the actual director of the Institute when Mesyatsev was unwell. In 1930 she became head of the newly established Laboratory on Marine Geology. In 1929, she headed the marine expeditions for the first time, thus becoming the first ever female scientist to lead such an expedition. She later recalled that there was a strong prejudice amongst sailors, who feared that a woman on a ship might cause a disaster, but she managed well with leading the scientific programme.

39. Zubov, 1933.

40. Valkova, 2008, p. 161.

41. Archives of Russian Academy of Sciences coll. 1758, inv. 1, f. 216, 1. 1-2.

42. Kalemeneva, Lajus, 2018.

43. For a short biography of one of his assistants, Tat'yana Dement'eva, and a photo of Professor Mesyatsev with a team of female scientists, see Zabelina, http://www.littorina.info/Aleksandrovsk/ ochevidci/dementyeva.htm (accessed 16 April 2021). 
As a marine geologist Klenova dealt with instruments such as geological tubes that needed to be handled carefully to maintain the sampling of sea floor sediments even in rough weather in a very small vessel. Other female scientists worked with plankton samplings by special nets or sampling of bottom fauna with dredges. The handling of all these instruments and the analysis of obtained materials in the laboratories on board and later at the coastal station often were in the hands of female scientists.

Applying this to the history of the formation and functioning of materiality in late Imperial and early Soviet oceanography, we can see that the research vessels and the instruments shaped the community of oceanographers. The focus on expertise as the determinant feature of being an oceanographer opened the way to the deconstruction and even neglect of gender borders. On the one hand, females needed to reject their gender to be on the equal stage with male scientists on board of ships; on the other hand, in the laboratory female researchers could be even more skillful than male when working with particular instruments and organizing carefully the laboratory life.

This narrative can be conceptualized through the perspective of specific role performed by instruments in the formation of modern science; indeed, it is well-known that instruments shaped the practices of research communities. This is true for the university, where in different departments "practices and [...] the instruments linked to them established new forms of learning and demarcated them from what was represented elsewhere in the university ${ }^{44 ”}$. In the marine sciences, where not only instruments but research vessels matter, more than demarcation, the integration of practices on one vessel was crucial for the establishment of a new research field.

\section{Sources}

Anonymous, ["Complains of Pomors»], Novoe vremia, n² 29, July 1900, p. 4 (in Russian).

Archives of Russian Academy of Sciences, coll. 1758 (Maria Klenova personal collection), inv. 1, f. 216, 1. 1-2.

" Augusta Palmquist », Atheneum for Girls 1881-1931: Memorial publication, Märta Edquist (ed.), Stockholm, 1931, p. 184-188.

44. Wiesenfeldt, 2008, p. 223-224. 
Breitfuss Leonid L, Kurzer Ueberblick ueber die Tatigkeit der wissenschaftlichen Murman expedition, 1898-1904, Mitteilungen des Deutschen SeefishereiVereins 1905, 7/8 (in German).

Hjort Johan, "N. M. Knipowitsch », Journal du Conseil xiv, n 3, 1939, p. 335-336.

KNipowitsch Nikolai M. Otchet nachal'nika Murmanskoi nauchno-promyslovoi ekspeditsii. Russian State Historical Archives. coll. 116, inv. 1, f. 17, 1. 38 (in Russian).

Knipowitsch Nikolai, Letter to Otto Pettersson, 24 September 1898, Universitetbiblioteket Gothenburg (in German).

Knipowitsch Nikolai, Letter to Otto Pettersson, 20 May 1900, Universitetbiblioteket Gothenburg (in German).

Knipowitsch Nikolai, Letter to Otto Pettersson, 24 December 1899. Universitetbiblioteket Gothenburg (in German).

Knipowitsch Nikolai, Letter to Otto Pettersson, 25 January 1902. Universitetbiblioteket Gothenburg (in German).

Knipowitsch Nikolai, Letter to Johan Hjort, 12 October 1901, Universitetbiblioteket Oslo (in German).

Knipowitsch Nikolai M., Kratkii otchet o poezdke za granitsu dlia oznakomleniia s postanovkoi rybnogo promysla i kasaiuschimisia ego nauchno-promyslovymi uchrezhdeniiami, St. Petersburg, 1897 (in Russian).

KNipowitsch Nikolai M., "Kratkii obzor rabot ekspeditsii dlia nauchno-promyslovukh issledovanii Murmana ", Izvestiia Akademii Nauk, seriia 5, $1900,12, n^{\circ} 5$, p. 419-469 (in Russian).

ODinTsov A.I. ["Means necessary for the scientific-fishery research"], Trudy Severnoi Komissii 1897-1898 gg., suppl. 1, Saint-Petersburg, 1898, p. 37-43 (in Russian).

Trudy Severnoi Komissii 1897-1898 gg. St. Petersburg, 1898 (in Russian).

VASNETsov V.A., Pod zvezdnym flagom «Perseia», Gidrometeoizdat, Leningrad, 1974 (in Russian).

Zabelina N.M., "Tat'yana Fedorovna Dement'eva: Rabota na "Persee” i na Murmanskoi biologicheskoi stantsii ", available online: http://www.littorina. info/Aleksandrovsk/ochevidci/dementyeva.htm (accessed 16 April 2021).

Zenkevich L. [Work by Floating Maritime Research Institute on board of the vessel Persei], Sovetskaia Arktika, n², 1941, p. 70-77.

Zubov Nikolai N, "The Circumnavigation of Franz Josef Land ", Geographical Review, 23, n 3, 1933, p. 394-401, p. 528. 
Julia Lajus

\section{Bibliography}

Bekasova Alexandra, "Voyaging towards the future: The brig Rurik in the North Pacific and the emerging science of the sea ", British Journal for the History of Science, 53, n 4, 2020, p. 469-495.

Boer Bas de, How Scientific Instruments Speak: Postphenomenology and Technological Mediations in Neuroscientific Practice, Rowman \& Littlefield, London, 2020.

Kalemeneva Ekaterina, Lajus Julia, "Soviet Female Experts in the Polar Regions ", in Ilic Melanie (ed.), The Palgrave Handbook of Women and Gender in Twentieth-Century Russia and the Soviet Union. Palgrave Macmillan, Cham, 2018, p. 267-283.

Kulikova Maria, "The Imperial Society for the Promotion of Russian Trade and Shipping and the "oil issue", 1875-1900", International Journal of Maritime History, 2018, 30, n 3, p. 526-535.

Lajus Julia, «Foreign Science in Russian Context : Murman Scientific-Fishery Expedition and Russian participation in early ICES activity ", ICES Marine Science Symposia, $\mathrm{n}^{\circ} 215,2002$, p. 64-72.

Lajus Julia, Svansson A., " Augusta Palmquist, a female Swedish Hydrographer Emissary to Russian Biologists on the Barents Sea in 1901 ", History of Oceanography. Abstracts of the VII International Congress on the History of Oceanography. Kaliningrad, September 8-12, 2003, p. 181-183.

Lajus Julia, [International cooperation, fish resources and development of fisheries science in Russia on the eve, during and after the First World War], Nauka, tekhnika i obschestvo Rossii i Germanii vo vremia Pervoi Mirovoi voiny, E.I. Kolchinsky, D. Beyrau, J. Lajus (eds), Nestor-Istoriia, Saint-Petersburg, 2007, p. 136-166 (in Russian).

Lajus Julia, "Field Stations on the Coast of the Arctic Ocean in the European Part of Russia from the First to Second IPY ", in SörLin S. (ed.), Science, Geopolitics and Culture in the Polar Region: Norden beyond Borders, Ashgate, Farnham, 2013a, p. 111-142.

Lajus Julia, "Linking People through Fish: Science and Barents Sea Fish Resources in the Context of Russian-Scandinavian Relations ", in SörLIN S. (ed.), Science, Geopolitics and Culture in the Polar Region: Norden beyond Borders, Ashgate, Farnham, 2013b, p. 171-194.

Lajus Julia, "Experts on Unknown Waters : Environmental Risk, Fisheries Science and Local Knowledge in the Russian North ", in Breyfogle N. (ed.). Eurasian Environments : Nature and Ecology in Imperial Russian and Soviet History, University of Pittsburg Press, Pittsburg, 2018, p. 205-220. 
Materiality of marine sciences in late Imperial Russia and early Soviet Union

McConnell Anita, "No Sea Too Deep »: The History of Oceanographic Instruments, Hilger, 1982.

Rozwadowski Helen, Vast Expanses: A History of the Oceans, Reaktion Books, London, 2018.

Rozwadowski Helen, The Sea Knows No Boundaries: A Century of Marine Science Under ICES, Seattle and London, 2002.

Solemdal Per, Serebryakov Valeri, "Cooperation in marine research between. Russia and Norway at the dawn of the 20th century ", ICES Marine Science Symposia, n ${ }^{\circ} 215,2002$, p. 73-86.

Svansson Artur, "Otto Pettersson, the Oceanographer (1848-1941) : Extracts from a Biography in Preparation ", in Morcos Selim et al. (eds.), Ocean Sciences Bridging the Millennia: A Spectrum of Historical Accounts. Proceeding of the vith International Congress on the History of Oceanography, UNESCO and China Ocean Press, Paris, 2004, p. 17-28.

Tsirkunov I.B., Arkticheskii korabl nauki, Murmanskoe knizhnoe izdatel' stvo, Murmansk, 2006.

VAlkova Olga, "The conquest of science: Women and science in Russia, 18601940 », Osiris, vol. 23, n 1, 2008, p. 136-165.

WiESENFELDT Gerhard, "The order of knowledge, of instruments, and of Leiden University, ca. 1700 ", in Lazardzig Jan, Schwarte Ludger, Schramm Helmar (eds.), Theatrum Scientiarum-English Edition, vol. 2, Instruments in Art and Science: On the Architectonics of Cultural Boundaries in the Seventeenth Century, De Gruyter, Berlin, 2008, p. 222-234.

\section{The author}

Julia Lajus has specialized in marine environmental history since the 1990s. She is Head of the Laboratory for Environmental and Technological History, Center for Historical Research, Higher School of Economics University, Russia. Her expertise is focused on the history of the late Imperial and early Soviet marine science. She authored many publications including « Soviet official critiques of the resource scarcity prediction by Limits to Growth report: the case of Evgenii Fedorov's ecological crisis rhetoric », European Review of History, 2020, vol. 27. n 3, p. 321-341; Ekaterina Kalemeneva, Julia Lajus, « Soviet Female Experts in the Polar Region », The Palgrave Handbook of Women and Gender in Twentieth-Century Russia and the Soviet Union, Palgrave Macmillan, 2018, p. 267-283. 